\title{
Reaction enhanced channelised fluid-flux along mid- crustal shear zone: An example from Mesoproterozoic Phulad Shear Zone, Rajasthan, India
}

\author{
Sadhana M Chatterjee*, Manideepa Roy Choudhury and Subhrajyoti Das \\ Department of Geological Sciences, Jadavpur University, Kolkata 700 032, India. \\ ${ }^{*}$ Corresponding author.e-mail: smcjugeo@gmail.com
}

\begin{abstract}
Fluid infiltration at great depth during regional metamorphism plays a major role in mass transport and is responsible for significant rheological changes in the rock. Calc-silicate rocks of the Kajalbas area of Delhi Fold Belt, Rajasthan, are characterised by foliation parallel alternate bands of amphibolerich and clinopyroxene-plagioclase feldspar-rich layers of varying thicknesses ( $\mathrm{mm}$ to decimetre thick). Textural relation suggests that the amphibole grains formed from clinopyroxene and plagioclase in the late phase of regional deformation. Algebraic analysis of the reaction textures and mineral compositions was performed with the computer program C-Space to obtain the balanced chemical reactions that led to the formation of amphibole-rich bands. The computed balanced reaction is 70.74 Clinopyroxene +27.23 Plagioclase $+22.018 \mathrm{H}_{2} \mathrm{O}+5.51 \mathrm{~K}^{+}+1.00 \mathrm{Mg}^{2+}+27.15 \mathrm{Fe}^{2+}=22.02$ Amphibole $+67.86 \mathrm{SiO}_{2}$ aqueous + $36.42 \mathrm{Ca}^{2+}+8.98 \mathrm{Na}^{+}$. The constructed reaction suggests that aqueous fluid permeated the calc-silicate rock along $\mathrm{mm}$ to decimetre thick channels, metasomatized the clinopyroxene-plagioclase bearing rocks to form the amphibole-rich layers. The regional deformation presumably created the fluid channels thereby allowing the metasomatic fluid to enter the rock system. The above reaction has large negative volume change for solid phases indicating reaction-induced permeability. Thermodynamic calculations suggest that the fluid-rock interaction occurred at $665 \pm 05^{\circ} \mathrm{C}$ and $6.6 \pm 0.25 \mathrm{kbar}$ (corresponding to $\sim 20$ $\mathrm{km}$ depth). Textural modeling integrating the textural features and balanced chemical reaction of the calc-silicate rocks of Mesoproterozoic Phulad Shear Zone thus indicate that extremely channelled fluid flow was reaction enhanced and caused major change in the rock rheology.
\end{abstract}

\section{Introduction}

Fluid infiltration during regional metamorphism is an important geologic process which may cause significant mass transfer of rock-forming elements (Fyfe et al. 1978; Etheridge et al. 1983; Ferry 1986; Ague 2003; Barnes et al. 2004). Channelised fluid flow of these elements may control the metamorphic reactions which in turn may cause significant change in the rock property (Connolly 2005). The mechanism for this channelised fluid flux at depth has been long debated; many views were discussed by different workers (Watson and Brenan 1987; Oliver 1996; Lewis et al. 1998; Jamtveit et al. 2000; Holness and Watt 2001; Nakamura and Watson 2001; Kostenko et al. 2002; Iyer et al. 2008; Ray et al. 2010). One such mechanism is associated with the volume changes (negative or positive changes) during metamorphic reactions. More often, the solid volume changes are negative under high $\mathrm{P} / \mathrm{T}$ conditions causing infiltration of fluid even in absence of external stress (Jamtveit et al. 2000).

Keywords. Channelised fluid-flux; metasomatism; calc-silicate rocks; Mesoproterozoic; Phulad Shear Zone; reactioninduced permeability. 
However, hydration reactions are associated with expansion of the solid volume that causes further fracturing and fluid infiltration. In the present paper, we have documented the evidence of extremely channelised fluid flow (less than mm thick) during hydration reaction from natural samples and explained the possible mechanism for the channelised fluid flow.

\section{Geological setting}

The Delhi Fold Belt (DFB) of the north-western Indian shield constitutes multiple-folded, polymetamorphosed rocks of Proterozoic age with a NE-SW trend (figure 1). The western margin of the DFB is demarcated by a narrow zone of intense deformation, running in north-easterly direction for several kilometres, known as the Phulad Shear Zone (PSZ) (Gupta et al. 1980; Sinha-Roy 1988; Golani et al. 1998; Ghosh et al. 1999). The PSZ is characterised by extensive development of a mylonite zone consisting mostly of inter-layered calc and quartzofeldspathic mylonites. The mylonitic foliation of the shear zone has a north-easterly

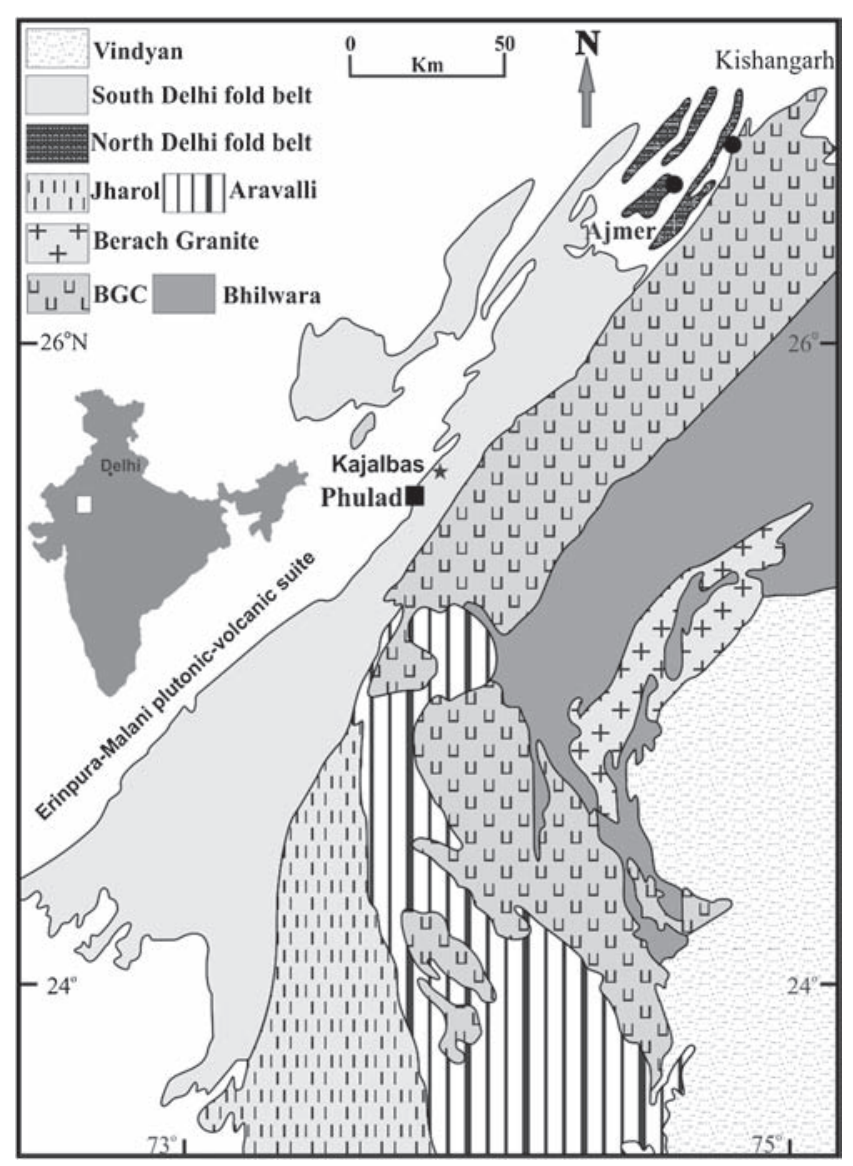

Figure 1. Geological map of parts of the Aravalli-Delhi fold belt, modified after Heron (1953) and Gupta et al. (1980). Star indicates the present study area. strike and a steep easterly dip with a very strong down-dip stretching lineation. Detailed structural studies by Sengupta and Ghosh $(2004,2007)$ indicate that the deformation in the shear zone is transpressional.

Kajalbas, the present study area (lat: $25^{\circ} 38^{\prime}$ $58.20^{\prime \prime} \mathrm{N}$, long: $73^{\circ} 49^{\prime} 48.90^{\prime \prime} \mathrm{E}$ ), is situated on the hanging wall side of PSZ, nearly a kilometre east of the proper shear zone (figure 1). The hanging wall of PSZ consists mostly of calc-silicate rocks inter-layered with pelitic schists, with few granites and amphibolites. The mylonitic foliation of PSZ shows a mean orientation of $34^{\circ} / 72^{\circ} \mathrm{E}$ with prominent development of down-dip stretching lineation (figure 2a). Although the rocks of hanging wall units are not mylonitic, they are intensely deformed. The mean orientation of the dominant foliation of the calc-silicate rocks of Kajalbas area is $37^{\circ} / 84^{\circ} \mathrm{E}$, with down-dip stretching lineation (figure $2 \mathrm{~b}$ ). The foliation and stretching lineation of these calcsilicate rocks are parallel to the mylonitic foliation and stretching lineation of the PSZ. The style and geometry of the structural elements, in both the PSZ and Kajalbas areas, suggest that the deformation was synchronous. The calc-silicate rocks of the Kajalbas area are composed of clinopyroxene and plagioclase minerals. These calc-silicate rocks are characterised by bands of amphibole-rich layers parallel to the dominant/regional foliation of the calc-silicate rocks. This study focuses on the formation of the amphibole layers of varying thickness parallel to the existing foliation of the calc-silicate rocks.

\section{Petrography}

Calc-silicate rocks of the Kajalbas area of PSZ are characterised by alternate banding of amphibolerich layers and clinopyroxene-plagioclase feldsparrich layers of varying thicknesses with few titanite grains as accessory phase in close association with the amphibole-rich bands. Veins of quartz often occur parallel to these amphibole-rich bands (figure 3a). The thickness of individual bands varies from tens of centimetres to less than a millimetre (figure 3). The calc-silicate rocks show strong development of foliation parallel to the compositional banding. This foliation-parallel compositional banding is strictly parallel to the regional foliation of the area. The clinopyroxene-plagioclase feldspar-rich layers show recrystallized and polygonal aggregates of clinopyroxene and plagioclase. The amphibolerich layers are distinctly coarse grained than that of clinopyroxene-plagioclase feldspar-rich layers. Amphibole grains are inequigranular in nature and vary in size from very coarse to medium sized grains and the volume percentage of amphibole within 


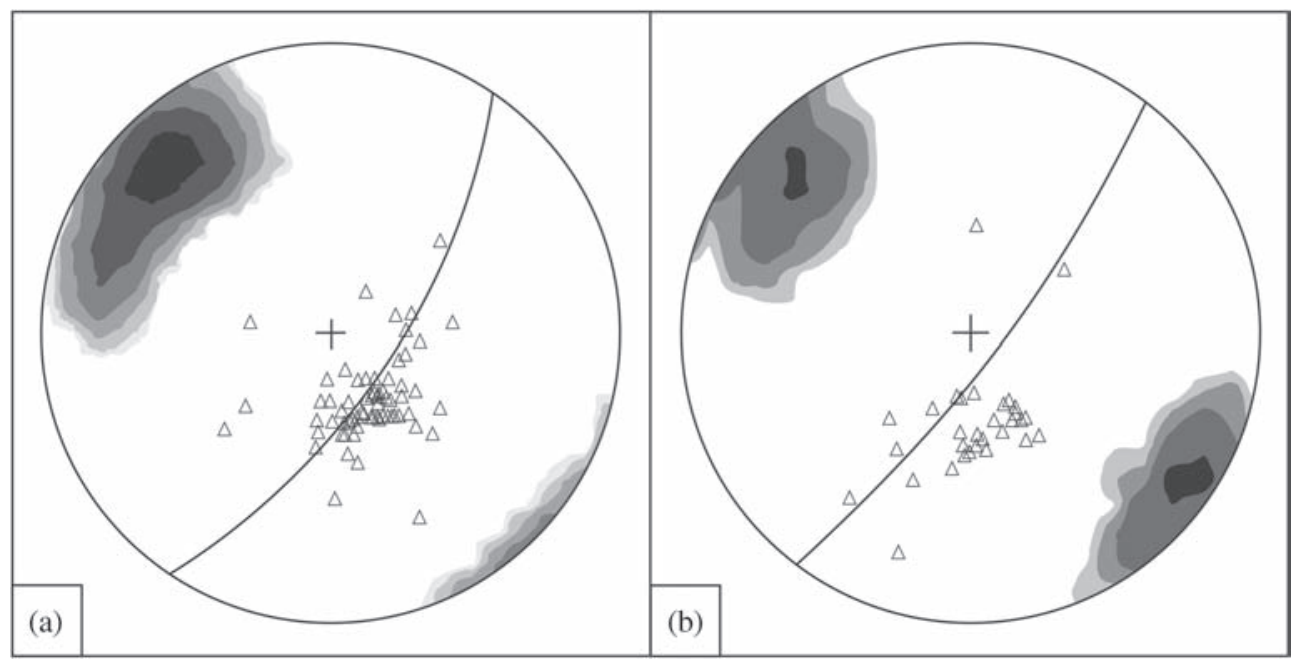

Figure 2. (a) Stereographic plot showing the $\pi$ girdle of the shear zone mylonitic foliation $(n=112)$ contoured at intervals of $1 \%, 2 \%, 4 \%, 8 \%, 16 \%$ and $32 \%$ (in increasing shades of grey; max $31.91 \%$ ). The mean principal orientation is $34^{\circ} / 72^{\circ} \mathrm{E}$. Open triangles are the stretching lineation $(n=64)$. The mean principal direction for the lineations is $67^{\circ} \rightarrow 152^{\circ}$. $(\mathbf{b})$ Stereographic plot showing the $\pi$ girdle of calc-silicate foliation $(n=56)$ contoured at intervals of $3 \%, 6 \%, 12 \%$ and $24 \%$ (in increasing shades of grey; max $27.78 \%$ ). The mean principal orientation is $37^{\circ} / 84^{\circ} \mathrm{E}$. Open triangles are the stretching lineation $(n=32)$. The mean principal direction for the lineations is $62^{\circ} \rightarrow 179^{\circ}$.

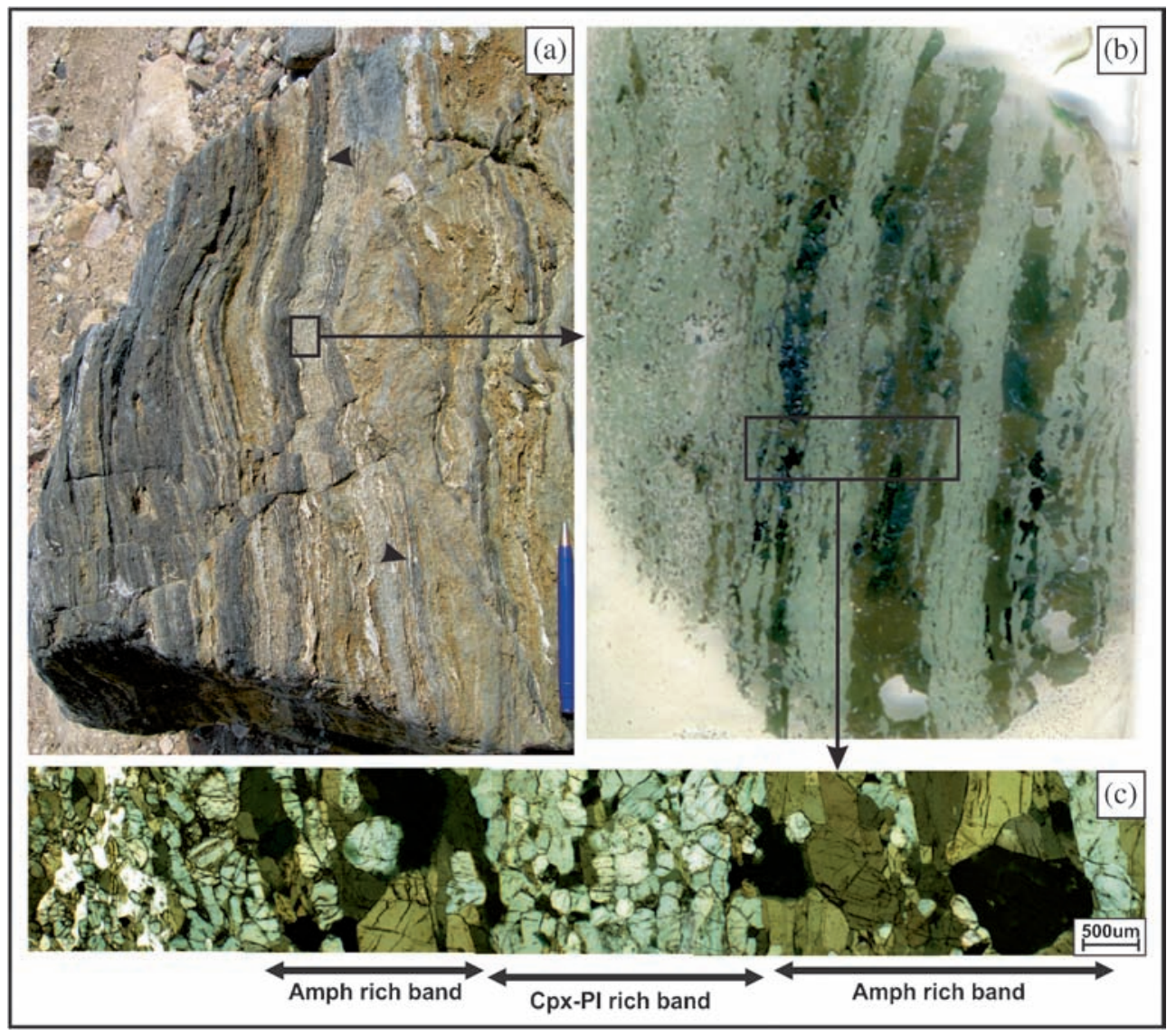

Figure 3. Calc-silicate rocks showing alternate bands of amphibole-rich layers and clinopyroxene-plagioclase feldspar-rich layers of varying thicknesses. (a) Field photograph showing the dark and light coloured banding. Quartz veins are marked by black arrow heads. (b) Photomicrograph (PPL image) shows the alternate amphibole-rich layer and clinopyroxene-plagioclase feldspar-rich layer. Width of the photograph is $2.5 \mathrm{~cm}$. (c) PPL image of box in B. PPL: Plane polarized light. 
these amphibole-rich layers is more than $90 \%$. Although, these amphibole-rich layers are parallel to the regional foliation plane, detailed study reveals that most of the amphibole grains within these bands are haphazardly oriented (figure 4a). However, some amphibole grains show recrystallized polygonal aggregates suggesting static recrystallization. These textural features suggest that amphibole grew in late phase of regional deformation of the host calcsilicate rocks. Within these amphibole-rich layers, the clinopyroxene and plagioclase mainly occur as included phases or as relict grains (figure $4 \mathrm{~b}$ ).
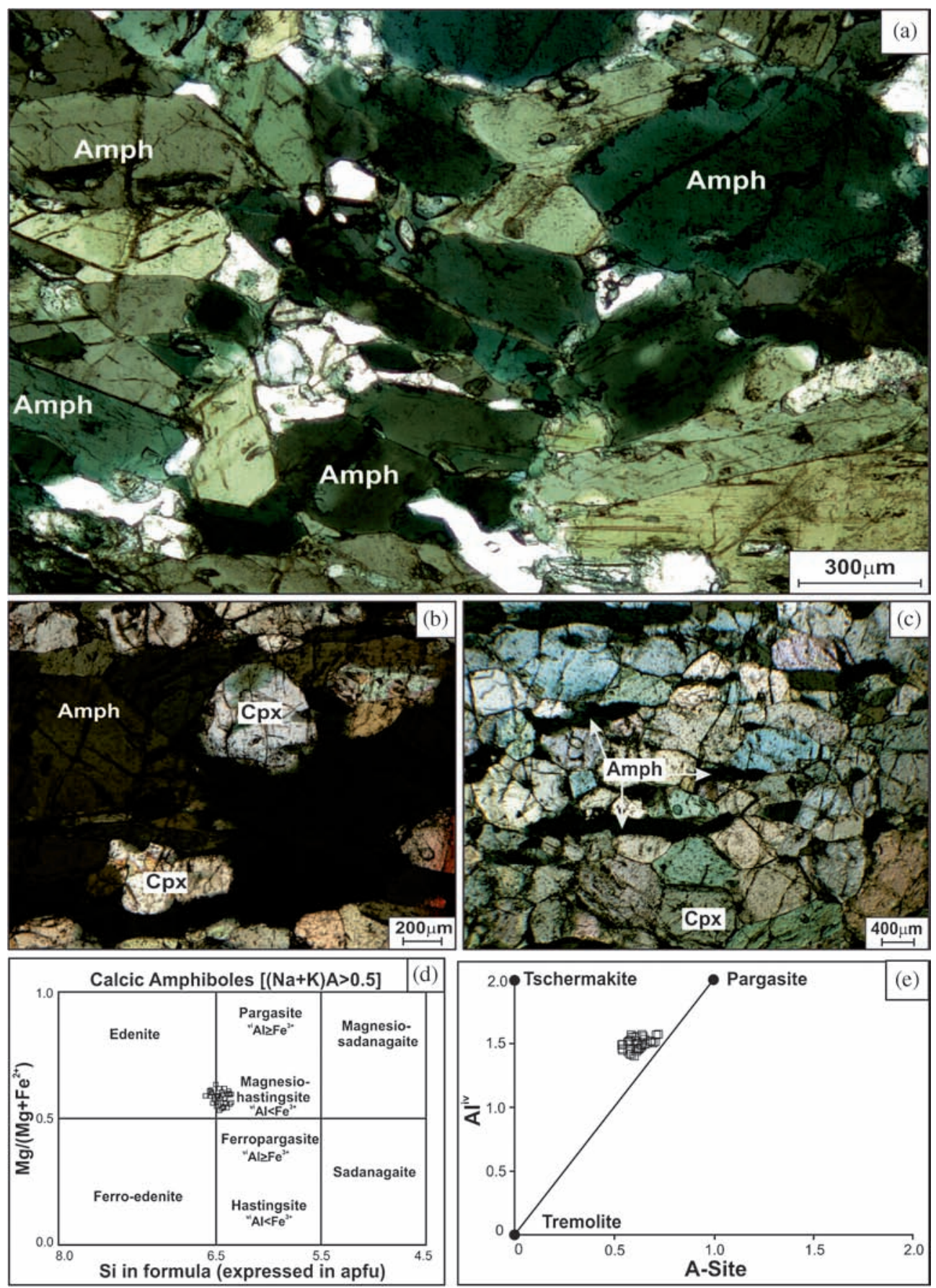

Figure 4. (a) Photomicrograph (PPL) shows the random orientation of amphibole grains within the amphibole-rich layers that are parallel to the regional foliation plane. (b) Photomicrograph (PPL) depicting the relict clinopyroxene grains within the amphibole-rich layer. (c) Photomicrograph (PPL) showing the growth of amphibole grains does not follow the grain boundary of plagioclase or clinopyroxene, rather along narrow channels. Note the polygonal aggregates of clinopyroxene and plagioclase in the matrix. (d) Classification of amphibole according to Leake et al. (1997) which shows the amphiboles are of magnesio-hastingsite with few pargasitic in composition. (e) Variation of amphibole compositions along $\mathrm{Al}^{\mathrm{IV}}$ vs. A site illustrating the pargasite $\rightarrow$ tremolite with few tschermakite $\rightarrow$ tremolite exchange vectors. PPL: Plane polarized light. 
Table 1. Electron probe microanalysis data and structural formulae of minerals relevant to the text.

\begin{tabular}{|c|c|c|c|c|c|c|c|c|c|c|c|c|}
\hline \multirow[b]{2}{*}{ Oxides } & \multicolumn{4}{|c|}{ Feldspar } & \multicolumn{4}{|c|}{ Amphibole } & \multicolumn{4}{|c|}{ Clinopyroxene } \\
\hline & rim & core & core & core & core & core & rim & rim & core & core & rim & rim \\
\hline $\mathrm{SiO}_{2}$ & 56.34 & 56.42 & 56.61 & 56.77 & 43.92 & 43.34 & 43.80 & 43.53 & 50.67 & 51.58 & 52.43 & 51.35 \\
\hline $\mathrm{TiO}_{2}$ & 0.03 & 0.00 & 0.00 & 0.00 & 0.57 & 0.60 & 0.54 & 0.56 & 0.04 & 0.04 & 0.03 & 0.01 \\
\hline $\mathrm{Al}_{2} \mathrm{O}_{3}$ & 27.02 & 27.18 & 27.00 & 27.03 & 10.81 & 11.56 & 11.62 & 10.37 & 1.49 & 1.38 & 0.64 & 1.35 \\
\hline $\mathrm{Cr}_{2} \mathrm{O}_{3}$ & 0.02 & 0.00 & 0.04 & 0.00 & 0.37 & 0.42 & 0.48 & 0.25 & 0.18 & 0.09 & 0.00 & 0.06 \\
\hline $\mathrm{FeO}$ & 0.21 & 0.19 & 0.32 & 0.13 & 16.05 & 16.47 & 16.10 & 15.55 & 9.13 & 8.90 & 9.39 & 8.86 \\
\hline $\mathrm{MnO}$ & 0.00 & 0.00 & 0.00 & 0.07 & 0.27 & 0.28 & 0.37 & 0.25 & 0.33 & 0.23 & 0.24 & 0.41 \\
\hline $\mathrm{MgO}$ & 0.00 & 0.02 & 0.01 & 0.01 & 10.40 & 10.06 & 10.05 & 11.00 & 12.32 & 12.71 & 12.83 & 12.52 \\
\hline $\mathrm{CaO}$ & 10.02 & 9.92 & 9.63 & 9.79 & 12.34 & 12.23 & 12.40 & 12.29 & 24.07 & 24.11 & 24.22 & 24.05 \\
\hline $\mathrm{Na}_{2} \mathrm{O}$ & 6.03 & 6.25 & 6.41 & 6.29 & 1.21 & 1.32 & 1.26 & 1.19 & 0.50 & 0.48 & 0.37 & 0.44 \\
\hline $\mathrm{K}_{2} \mathrm{O}$ & 0.17 & 0.12 & 0.17 & 0.12 & 1.29 & 1.39 & 1.35 & 1.24 & 0.00 & 0.00 & 0.02 & 0.00 \\
\hline Total & 99.83 & 100.11 & 100.18 & 100.21 & 97.23 & 97.66 & 97.97 & 96.23 & 98.72 & 99.50 & 100.16 & 99.05 \\
\hline $\mathrm{O}_{2}$ basis & 8.00 & 8.00 & 8.00 & 8.00 & 23.00 & 23.00 & 23.00 & 23.00 & 6.00 & 6.00 & 6.00 & 6.00 \\
\hline $\mathrm{Si}$ & 2.54 & 2.54 & 2.55 & 2.54 & 6.60 & 6.50 & 6.55 & 6.58 & 1.94 & 1.96 & 1.94 & 1.92 \\
\hline $\mathrm{Ti}$ & 0.00 & 0.00 & 0.00 & 0.00 & 0.06 & 0.07 & 0.06 & 0.06 & 0.00 & 0.00 & 0.00 & 0.00 \\
\hline $\mathrm{Al}$ & 1.44 & 1.44 & 1.43 & 1.43 & 1.91 & 2.04 & 2.05 & 1.85 & 0.06 & 0.03 & 0.06 & 0.07 \\
\hline $\mathrm{Cr}$ & 0.00 & 0.00 & 0.00 & 0.00 & 0.04 & 0.05 & 0.06 & 0.03 & 0.00 & 0.00 & 0.00 & 0.01 \\
\hline $\mathrm{Fe}^{3+}$ & 0.01 & 0.01 & 0.01 & 0.01 & 0.12 & 0.15 & 0.08 & 0.25 & 0.10 & 0.08 & 0.10 & 0.13 \\
\hline $\mathrm{Fe}^{2+}$ & 0.00 & 0.00 & 0.00 & 0.00 & 1.89 & 1.92 & 1.94 & 1.72 & 0.18 & 0.21 & 0.18 & 0.16 \\
\hline $\mathrm{Mn}$ & 0.00 & 0.00 & 0.00 & 0.00 & 0.03 & 0.04 & 0.05 & 0.03 & 0.01 & 0.01 & 0.01 & 0.01 \\
\hline $\mathrm{Mg}$ & 0.00 & 0.00 & 0.00 & 0.00 & 2.33 & 2.25 & 2.24 & 2.48 & 0.71 & 0.71 & 0.70 & 0.70 \\
\hline $\mathrm{Ca}$ & 0.48 & 0.48 & 0.47 & 0.46 & 1.99 & 1.97 & 1.99 & 1.99 & 0.97 & 0.97 & 0.97 & 0.98 \\
\hline $\mathrm{Na}$ & 0.53 & 0.55 & 0.55 & 0.56 & 0.35 & 0.38 & 0.36 & 0.35 & 0.04 & 0.03 & 0.03 & 0.04 \\
\hline K & 0.01 & 0.01 & 0.01 & 0.01 & 0.26 & 0.27 & 0.26 & 0.24 & 0.00 & 0.00 & 0.00 & 0.00 \\
\hline \# Cation & 5.01 & 5.02 & 5.01 & 5.02 & 15.60 & 15.63 & 15.61 & 15.58 & 4.00 & 4.00 & 4.00 & 4.00 \\
\hline
\end{tabular}

Clinopyroxene grains in the amphibole-rich domains are highly fractured with corroded grain boundary. At places, where the distinct amphibole-rich bands have not developed, clusters of coarse amphibole grains have formed within the matrix of clinopyroxene-plagioclase feldspar. Though these clusters are not interconnected, they follow the general foliation of the rock. Even growths of a single amphibole grain do not follow the grain boundaries of the pre-existing pyroxene and plagioclase, rather developed along channels (figure 4c).

\section{Mineral chemistry}

Compositions of minerals were obtained by the Electron Probe Micro Analyzer in the Central Petrological Laboratory, Geological Survey of India (GSI), Kolkata (India), with a CAMECA SX 100 model (table 1). The accelerating voltage was $15 \mathrm{kV}$; beam current $15 \mathrm{nA}$ and beam size 1 micron. Natural standards were used for calibrations of all elements, except Mn and Ti for which synthetic standards from BRGM were used. Plagioclase does not show any distinct compositional zoning $\left(\mathrm{X}_{\mathrm{An}}=\right.$ 0.46-0.48). Although clinopyroxene shows textural variation in different layers, it is compositionally homogeneous $\left(\mathrm{X}_{\mathrm{Mg}}=0.79, \mathrm{Al}_{2} \mathrm{O}_{3}=0.84 \mathrm{wt} \%\right.$ ). Amphiboles are chemically magnesio-hastingsite (after Leake et al. 1997) with few being pargasitic in composition (figure 4d). Major amphibole substitution straddle between the pargasite $\rightarrow$ tremolite $\left(\mathrm{Na}^{\mathrm{A}}+2 \mathrm{Al}^{\mathrm{IV}}+\mathrm{Al}^{\mathrm{VI}} \rightarrow \square+2 \mathrm{Si}^{\mathrm{IV}}+\mathrm{Mg}^{\mathrm{VI}}\right)$, with few tschermakite $\rightarrow$ tremolite $\left(2 \mathrm{Al}^{\mathrm{IV}}+2 \mathrm{Al}^{\mathrm{VI}} \rightarrow 2 \mathrm{Si}^{\mathrm{IV}}+\right.$ $\mathrm{Mg}^{\mathrm{VI}}$ ), exchange vectors (figure $4 \mathrm{e}$ ).

\section{Mineral reactions}

Mineral reaction that produced amphibole from clinopyroxene and plagioclase can be derived from algebraic analysis of the observed mineral compositions. The computer program C-Space (TorresRoldán et al. 2000) was used to obtain the balanced chemical reaction and the required compositional matrix is presented in Appendix. The results of the analyses return the following amphibole forming reaction:

70.74 Clinopyroxene +27.23 Plagioclase

$$
\begin{aligned}
& +22.018 \mathrm{H}_{2} \mathrm{O}+5.51 \mathrm{~K}^{+} \\
& +1.00 \mathrm{Mg}^{2+}+27.15 \mathrm{Fe}^{2+}
\end{aligned}
$$




$$
\begin{aligned}
= & 22.02 \text { Amphibole }+67.86 \mathrm{SiO}_{2} \text { aqueous } \\
& +36.42 \mathrm{Ca}^{2+}+8.98 \mathrm{Na}^{+} .
\end{aligned}
$$

Reaction (1) suggests that in order to produce amphibole-rich bands from the clinopyroxeneplagioclase bearing rocks infiltration of $\mathrm{Fe}^{2+}$ and $\mathrm{K}^{+}$rich fluids is necessary. The fluid-rock interaction also releases significant amount of silica, $\mathrm{Ca}^{2+}$ and $\mathrm{Na}^{+}$. The released silica possibly explains the occurrences of quartz veins parallel to the amphibole-rich bands in few locales (Walther and Wood 1986; Saishu et al. 2010). Since no other new mineral was found near amphibole, it is presumed that the percolated fluid carried other elements out of the system.

Reaction (1) also shows that the amphibole forming reaction has large negative volume $(\Delta V=$ -196.18 j/bar; Holland and Powell 1998) for the solid phases. This large negative volume change can create its own porosity and permeability, hence facilitating infiltration and mass transfer through the rock. Thus the formation of amphibole can proceed even in absence of external stress. Gross $\Delta V$ of the reaction also shows large negative volume of $\Delta V=-242.84 \mathrm{j} /$ bar. Perple_X program of Connolly (2005) was used to calculate the molar volume of water at $650^{\circ} \mathrm{C}$ and 6 kbar.

Quantitative estimation of the temperature of metasomatic reaction was estimated using the edenite-richterite thermometric formulations of Holland and Blundy (1994) for rim compositions of plagioclase and nearest neighbour hornblende which yields a temperature range of $665 \pm 05^{\circ} \mathrm{C}$. This thermometer was chosen as the mineral assemblage of the present calc-silicate rocks is devoid of quartz. Quantitative estimation of the pressure of metasomatic reaction was done using the geobarometer of Hammarstrom and Zen (1986) based on total $\mathrm{Al}\left(\mathrm{Al}^{\mathrm{T}}\right)$ content in hornblende which yields a pressure range of $6.36 \pm 0.8 \mathrm{kbar}$ and the barometric formulations of Anderson (1996) which yields a pressure range of $6.85 \pm 0.5 \mathrm{kbar}$.

\section{Discussion and conclusion}

Textural modeling integrating the textural features and balanced chemical reaction suggests that the amphibole forming reaction promotes the reduction of solid volume which possibly increased the permeability in the rock system. The aqueous fluid thus infiltrated in the calc-silicate rocks along $\mathrm{mm}$ to decimetre thick channels and metasomatized the clinopyroxene-plagioclase bearing rocks to form the amphibole-rich layers. The growth of amphibole-rich layers is restricted along the foliation domains of the rock indicating the permeability of the fluid along the foliation was greater than across the foliation (Ferry 1994; Ingebritsen and Manning 1999). This suggests that the regional foliation created the fluid channels and allowed the metasomatic fluid to enter the rock system. Since the amphibole forming reaction has large negative volume change for solid phases, the operation of such metasomatic reaction created its own porosity and permeability so that more fluid was allowed to percolate through the rock system. Thus the formation of amphibole could proceed even in the absence of external stress. The textural evidence in the present study corroborates this fact. During this metasomatic alteration, the host rock gained $\mathrm{K}$ and $\mathrm{Fe}$ and released silica, $\mathrm{Ca}$ and $\mathrm{Na}$. Thus, the early anhydrous assemblage of clinopyroxene-plagioclase feldspar was replaced by bands of hydrous amphibole by metasomatic reaction that caused rheological changes in the rock. Thermodynamic calculations suggest that the fluid-rock interaction occurred at $665 \pm 05^{\circ} \mathrm{C}$ and $6.6 \pm 0.25 \mathrm{kbar}$ (corresponding to $\sim 20 \mathrm{~km}$ depth). Although the present study cannot pinpoint the source of the metasomatic fluid, close occurrence of granitic body or fluid released from dehydration reaction of the intercalated pelitic rocks can be considered as a possible source.

This work, therefore, documents the evidence of extremely channelised fluid flux (less than $\mathrm{mm}$ to decimetre thick conduit) that was developed in the mid-crustal ductile shear zone. It also highlights the fact that the fluid rock metasomatic reaction creates the porosity and permeability in the rock system which further enhanced the channelised fluid flux and caused major changes in rheological property of the rock.

\section{Acknowledgements}

SMC acknowledges the financial support from Department of Science and Technology, New Delhi (India) for funding a research project and CAS, Department of Geological Sciences, Jadavpur University, Kolkata. The authors are grateful to Prof S Sengupta for her support during the field work. We thank Mr A Chatterjee for his help during the initial part of the work. The authors are thankful to Prof P Sengupta for his useful discussions during the preparation of the manuscript. The authors appreciate the constructive comments by the anonymous reviewer that improved the clarity of the manuscript. 


\section{Appendix: Compositional matrix for textural modeling}

\begin{tabular}{lcccccccccc}
\hline Phase \# & $\mathrm{Si}$ & $\mathrm{Ti}$ & $\mathrm{Al}$ & $\mathrm{Fe}$ & $\mathrm{Mg}$ & $\mathrm{Ca}$ & $\mathrm{Na}$ & $\mathrm{K}$ & $\mathrm{O}$ & $\mathrm{H}$ \\
\hline Amph & 6.32 & 0.07 & 1.91 & 2.10 & 2.40 & 2.00 & 0.35 & 0.26 & 24.00 & 2.00 \\
$\mathrm{Cpx}$ & 1.95 & 0.00 & 0.04 & 0.27 & 0.73 & 0.96 & 0.03 & 0.00 & 6.00 & 0.00 \\
$\mathrm{Plag}$ & 2.54 & 0.00 & 1.45 & 0.00 & 0.00 & 0.47 & 0.54 & 0.01 & 8.00 & 0.00 \\
$\mathrm{SiO}_{2}$ aq & 1.00 & 0.00 & 0.00 & 0.00 & 0.00 & 0.00 & 0.00 & 0.00 & 2.00 & 0.00 \\
$\mathrm{H}_{2} \mathrm{O}$ & 0.00 & 0.00 & 0.00 & 0.00 & 0.00 & 0.00 & 0.00 & 0.00 & 1.00 & 2.00 \\
$\mathrm{Ca}$ & 0.00 & 0.00 & 0.00 & 0.00 & 0.00 & 1.00 & 0.00 & 0.00 & 0.00 & 0.00 \\
$\mathrm{~K}$ & 0.00 & 0.00 & 0.00 & 0.00 & 0.00 & 0.00 & 0.00 & 1.00 & 0.00 & 0.00 \\
$\mathrm{Na}$ & 0.00 & 0.00 & 0.00 & 0.00 & 0.00 & 0.00 & 1.00 & 0.00 & 0.00 & 0.00 \\
$\mathrm{Mg}$ & 0.00 & 0.00 & 0.00 & 0.00 & 1.00 & 0.00 & 0.00 & 0.00 & 0.00 & 0.00 \\
$\mathrm{Fe}$ & 0.00 & 0.00 & 0.00 & 1.00 & 0.00 & 0.00 & 0.00 & 0.00 & 0.00 & 0.00 \\
\hline
\end{tabular}

\section{References}

Ague J J 2003 Fluid infiltration and transport of major, minor and trace elements during regional metamorphism of carbonate rocks, Wapawaug Schist, Connecticut, USA; Am. J. Sci. 303 753-816.

Anderson J L 1996 Status of thermobarometry in granitic batholiths; Trans. Roy. Soc. Edin. Earth 87 125-138.

Barnes J D, Selverstone J and Sharp Z D 2004 Interactions between serpentinite devolatilization, metasomatism and strike-slip strain localization during deep-crustal shearing in the eastern Alps; J. Metamorph. Geol. 22 283-300.

Connolly J A D 2005 Computation of phase equilibria by linear programming: A tool for geodynamic modelling and its application to subduction zone decarbonation; Earth Planet. Sci. Lett. 236 524-541.

Etheridge M A, Wall V J and Vernon R H 1983 The role of the fluid phase during regional metamorphism and deformation; J. Metamorph. Geol. 1 205-226.

Ferry J M 1994 Overview of the petrologic record of fluid flow during regional metamorphism in northern New England; Am. J. Sci. 294 905-988.

Ferry J M 1986 Reaction progress: A monitor of fluidrock interaction during metamorphic and hydrothermal events; In: Fluid-Rock Interactions during Metamorphism (eds) Walther J V and Wood B J, Springer, New York, pp. 60-88.

Fyfe W S, Price N J and Thompson A B 1978 Fluids in the Earth's crust: Their significance in metamorphic tectonic and chemical transport processes; Elsevier, Amsterdam, $372 \mathrm{p}$.

Ghosh S K, Hazra S and Sengupta S 1999 Planar, nonplanar and refolded sheath folds in Phulad Shear Zone, Rajasthan, India; J. Struct. Geol. 21 1715-1729.

Golani P R, Reddy A B and Bhattacharjee J 1998 The Phulad Shear Zone in central Rajasthan and its tectonostratigraphic implications; In: The Indian Precambrian (ed.) Paliwal B S, Scientific Publishers (India), Jodhpur, pp. $272-278$.

Gupta S N, Arora Y K, Mathur R K, Iqbaluddin Prasad B, Sahai T N and Sharma S B 1980 Lithostratigraphic map of the Aravalli region, southern Rajasthan and northeastern Gujarat; Geological Survey of India Publication.

Hammarstrom J M and Zen E-an 1986 Aluminum in hornblende: An empirical igneous geobarometer; Am. Mineral. 71 1297-1313.

Heron A M 1953 Geology of Central Rajputana; Memoir Geol. Surv. India $\mathbf{7 9} 339$.

Holland T and Blundy J 1994 Non-ideal interactions in calcic amphiboles and their bearing on amphiboleplagioclase thermometry; Contrib. Mineral. Petrol. 116 433-447.
Holland T J B and Powell R 1998 An internally-consistent thermodynamic dataset for phases of petrological interest; J. Metamorph. Geol. 16 309-344.

Holness M B and Watt G R 2001 Quartz recrystallization and fluid flow during contact metamorphism: A cathodoluminescence study; Geofluids 1 215-228.

Ingebritsen S E and Manning C E 1999 Geological implications of a permeability-depth curve for the continental crust; Geology 27 1107-1110.

Iyer K, Jamtveit B, Mathiesen J, Malthe-Sørenssen A and Feder J 2008 Reaction-assisted hierarchical fracturing during serpentinization; Earth Planet. Sci. Lett. 267 503-516.

Jamtveit B, Austrheim H and Malthe-Sorenssen A 2000 Accelerated hydration of the Earth's deep crust induced by stress perturbations; Nature 408 75-78.

Kostenko O, Jamtveit B and Austrheim H 2002 The mechanism of fluid infiltration in peridotites at Almklovdalen, western Norway; Geofluids 2 203-215.

Leake B E et al. 1997 Nomenclature of amphiboles: Report of the subcommittee on amphiboles of the International Mineralogical Association, Commission on new minerals and minerals names; Can. Mineral. 35 219-246.

Lewis S, Holness M and Graham C 1998 Ion microprobe study of marble from Naxos, Greece: Grain-scale fluid pathways and stable isotope equilibration during metamorphism; Geology 26 935-938.

Nakamura M and Watson E B 2001 Experimental study of aqueous fluid infiltration into quartzite: Implications for the kinetics of fluid redistribution and grain growth driven by interfacial energy reduction; Geofluids 1 73-89.

Oliver N H S 1996 Review and classification of structural controls on fluid flow during regional metamorphism; J. Metamorph. Geol. 14 477-492.

Ray S, Sanyal S and Sengupta P 2010 Mineralogical Control on Rheological Inversion of a Suite of Deformed Mafic Dykes from Parts of the Chottanagpur Granite Gneiss Complex of Eastern India; (ed.) Srivastava R K, In: Dyke Swarms: Keys for Geodynamic Interpretation, pp. 263-276.

Saishu H, Okamoto A and Tsuchiya N 2010 Precipitation of silica minerals in hydro thermal flow-through experiments; In: Water-rock interaction (eds) Birkle P and Torres-Alvarado I S, CRC Press, London, pp. 669-672.

Sengupta S and Ghosh S K 2004 Analysis of transpressional deformation from geometrical evolution of mesoscopic structures from Phulad Shear Zone, Rajasthan, India; J. Struct. Geol. 26 1961-1976.

Sengupta S and Ghosh S K 2007 Origin of striping lineation and transposition of linear structures in shear zones; J. Struct. Geol. 29 273-287. 
Sinha-Roy S 1988 Wilson cycles in Rajasthan; In: Precambrians of Aravalli Mountain Range (ed.) Roy A B, Memoir Geol. Soc. India 9 95-107.

Torres-Roldán R L, García-Casco A and Garcíasánchez P A 2000 C Space: An integrated workplace for the graphical and algebraic analysis of phase assemblages on 32-bit Wintel platforms; Comput. Geosci. 26 779-793.
Walther J V and Wood B J 1986 Fluid-rock interaction during metamorphism; Springer-Verlag, New York, pp. $123-127$.

Watson E B and Brenan J M 1987 Fluids in the lithosphere. 1. Experimentally determined wetting characteristics of $\mathrm{CO}_{2}-\mathrm{H}_{2} \mathrm{O}$ fluids and their implications for fluid transport, host-rock physical-properties, and fluid inclusion formation; Earth Planet. Sci. Lett. 85 497-515.

MS received 29 September 2015; revised 21 June 2016; accepted 27 June 2016

Corresponding editor: Pulak Sengupta 